K A N D A I

\begin{tabular}{|l|l|l|}
\hline Volume 16 & No. 2, November 2020 & Halaman 259-273 \\
\hline
\end{tabular}

\title{
FENOMENA CAMPUR KODE \\ DALAM NOVEL METROPOP ANTOLOGI RASA KARYA IKA NATASSA (Mixed-codes Phenomenon in the Metropop Novel of Antologi Rasa by Ika Natassa)
}

\author{
Tania Intan \& Vincentia Tri Handayani \\ Fakultas Ilmu Budaya, Universitas Padjadjaran \\ Jl. Raya Bandung-Sumedang Km. 21,7 Jatinangor, Indonesia \\ Pos-el: tania.intan@unpad.ac.id
}

(Diterima: 9 Februari 2019; Direvisi: 29 Juni 2019; Disetujui: 9 November 2020)

\begin{abstract}
This research was conducted to uncover the phenomenon of code mixing in the Ika Natassa's novel of Antologi Rasa by using descriptive qualitative method and sociolinguistic approach. The frame of research concept is based on theoretical references that relate sociolinguistics, bilingualism-plurilingualism, with code-mixed-code switching. From the data collected, there are mixed codes in the form of (1) word insertion which is then divided into word classes, namely nouns, adjectives, conjunctions, and interjections, (2) insertion of phrases in nominal phrases, prepositional phrases, and adjunctival phrases, (3) baster insertion, (4) clause insertion, and (5) idiom insertion. The research also shows that the characters and narrators in the novel of Antologi Rasa, namely: Keara, Harris, and Ruly, are shown as bilingual metropolitan young figures who actively and consistently use a combination of Indonesian and English to communicate. The characters, especially Keara and Harris, seem very free to practice code mixing, both when talking to other characters and speaking inwardly. The use of mixed code can be considered to support the categorization and labeling of the Antologi Rasa novel as a popular metropolitan work.

Keywords: mixed code, form, linguistic-non-linguistic factors, metropop
\end{abstract}

\begin{abstract}
Abstrak
Penelitian ini dilakukan untuk mengungkap fenomena campur kode di dalam novel Antologi Rasa karya Ika Natassa dengan menggunakan metode deskriptif kualitatif dan pendekatan sosiolinguistik. Kerangka konsep penelitian ini dilandasi oleh referensi teoretis yang mengaitkan sosiolinguistik, bilingualisme-plurilingualisme, dan alih kode-campur kode. Dari data yang dikumpulkan, terdapat wujud campur kode berupa (1) penyisipan kata yang kemudian dibagi atas kelas kata, yaitu nomina, adjektiva, konjungsi, dan interjeksi, (2) penyisipan frasa berupa frasa nominal, frasa preposisional, dan frasa adjektival, (3) penyisipan baster, (4) penyisipan klausa, dan (5) penyisipan idiom. Penelitian juga menunjukkan bahwa para tokoh dan narator di dalam novel Antologi Rasa, yaitu: Keara, Harris, dan Ruly, ditampilkan sebagai sosok-sosok muda metropolitan bilingual yang secara aktif dan konsisten menggunakan kombinasi bahasa Indonesia dan bahasa Inggris untuk berkomunikasi. Para tokoh, terutama Keara dan Harris, tampak sangat leluasa mempraktikkan campur kode, baik saat berbicara dengan tokoh-tokoh lain, maupun ketika bertutur di dalam hati. Penggunaan campur kode dapat dianggap menunjang kategorisasi dan labelisasi novel Antologi Rasa sebagai sebuah karya metropolitan-populer (metropop). Kata-kata kunci: campur kode, wujud, faktor linguistik-non linguistik, metropop
\end{abstract}




\section{PENDAHULUAN}

Antologi Rasa (Natassa, 2018) karangan Ika Natassa adalah sebuah novel metropop yang bercerita tentang tokoh Keara Tedjasukmana dan kehidupan cintanya. Keara adalah seorang perempuan muda, cerdas, mandiri, dan mapan. Ia bekerja di sebuah bank besar di Jakarta setelah menyelesaikan studinya di Amerika. Keara menganut gaya hidup hedonis, gemar minum wine, dan bertualang cinta, tidak jauh berbeda dengan Harris Risjad, teman sekantornya. Harris langsung jatuh hati pada perempuan itu sejak pertama kali mereka bertemu. Namun, Keara lebih menyukai Ruly Walantaga. Mereka bertiga dan Denise kemudian menjadi sahabat. Kehidupan Ruly yang jauh dari kemewahan, alim, dan selalu bersikap baik pada semua orang membuat Keara mencintainya. Harris yang lebih menyerupai dirinya hanya disukai Keara sebagai teman saja. Ruly ternyata lebih menyukai Denise yang telah bersuami. Semua hubungan yang tidak berjalan baik dan saling silang ini membuat masing-masing mencari pelarian dari cinta mereka yang bertepuk sebelah tangan. Akhir cerita tidak menjelaskan bagaimana hubungan di antara keempat tokoh tersebut selanjutnya.

Penulis Antologi Rasa, Ika Natassa, lahir di Medan tanggal 25 Desember 1977. Ia menyelesaikan pendidikan sekolah menengah dasar di lowa dan melanjutkan studinya di bidang ekonomi. Sebelum menjadi penulis, Ika adalah seorang bankir yang berprestasi di bank Mandiri. Setelah serius menekuni dunia literasi, dalam karyakaryanya yang hampir selalu menjadi best-sellers, Ika mengangkat kehidupan kaum urban dengan sisipan romansa. Karya-karya Ika Natassa meliputi $A$ Very Yuppy Wedding (2007), Divortiaire (2008), Underground (2010), Antologi Rasa (2011), Trivortiaire (2012), Trivortiaire 2 (2014), Critical Eleven (2015), The Architecture of Love (2016), Susah Sinyal (2018, bekerja sama dengan Ernest Prakasa), dan Heartbreak Motel (2019). Beberapa novel Ika juga telah diekranisasi, seperti Critical Eleven (2017) dan Antologi Rasa (2019). Tiga novelnya yang lain yaitu $A$ Very Yuppy Wedding, The Architecture of love, dan Trivortiaire direncanakan akan dibuat filmnya.

Dalam Antologi Rasa, dapat dideteksi adanya fenomena campur kode yang intens seperti yang terbaca pada setiap halamannya yang secara keseluruhan berjumlah 344 halaman. Alur utama cerita memang menggunakan bahasa Indonesia. Namun, setiap narator dan para tokoh kerap bertutur secara silih berganti dalam bahasa Inggris dan bahasa Indonesia yang mewujud pada karakter bilingual yang fasih dan leluasa menggunakan kedua bahasa tersebut. Penelitian ini dilakukan untuk mengupas gejala campur kode yang terjadi di dalam sebuah 'masyarakat fiktif', yaitu para tokoh di dalam novel kontemporer.

Kajian terhadap fenomena campur kode dalam karya sastra telah beberapa kali dilakukan, di antaranya dalam penelitian Rochmani, dkk. (Rochmani, Siti, 2013) terhadap novel Negeri 5 Menara karya Ahmad Fuadi, Wahyuti (Wahyuti, 2013) terhadap novel $5 \mathrm{~cm}$ karya Donny Dhirgantoro, dan Rahmasari (Rahmasari, 2017) terhadap novel The Chocolate Heart karya Laura Florand. Pengkajian terhadap novel Antologi Rasa juga telah beberapa kali 
dilakukan, di antaranya melalui penelitian yang berkaitan dengan aspek sosial budaya oleh Komariyati (Komariyati, 2017), gaya hidup hedonisme oleh Andelweis dkk. (Andelwis, 2014), dan konsep maskulin oleh Harum (Harum, 2018). Namun demikian, penelitian mengenai fenomena campur kode dalam novel Antologi Rasa karya Ika Natassa belum pernah dilakukan sehingga masih ada ruang bagi peneliti untuk membahasnya.

Nababan (1991:

mengungkapkan bahwa yang dimaksud dengan campur kode adalah percampuran dua atau lebih bahasa atau ragam bahasa dalam suatu tindak bahasa (speech act atau discourse) tanpa ada sesuatu dalam situasi berbahasa itu yang menuntut pencampuran bahasa. Lebih lanjut dikatakan bahwa dalam situasi tersebut tidak ada situasi yang menuntut pembicara, hanya masalah kesantaian dan kebiasaan yang dituruti oleh pembicara. Dari latar belakang sosial tokoh-tokoh yang ada pada novel ini terutama Keara dan Harris, tak dapat dipungkiri, penggunaan campur kode banyak dipengaruhi kebiasaan yang dilakukan secara spontan karena kemampuan berbahasa Inggris yang dominan. Sebagai contoh, Keara kerap berbicara dalam hatinya sendiri atau memaki-maki dalam bahasa Inggris, karena mungkin dalam bahasa tersebut ada istilah atau ungkapan yang terasa lebih mengena baginya daripada dalam Bahasa Indonesia.

Agar penelitian ini lebih terarah dan sistematis, pertanyaan penelitian telah dirumuskan sebagai berikut: bagaimana wujud campur kode yang ditampilkan dalam novel Antologi Rasa dan apa faktor penyebab terjadinya campur kode tersebut.

\section{LANDASAN TEORI}

Untuk membatasi wilayah kajian, referensi teoretis yang relevan dan terkait dengan sosiolinguistik, bilingualisme, multilingualisme, alih kode-campur kode, serta konteks dan koteks akan digunakan.

Pembahasan campur kode berada dalam wilayah kajian sosiolinguistik, yaitu ilmu yang mempelajari penggunaan bahasa dalam masyarakat (Partana, 2002). Dari segi penutur bahasa, Nababan (1991: 2) menyatakan bahwa penutur bahasa senantiasa berinteraksi dengan menggunakan bahasa. Setiap individu akan berkumpul dalam satu lingkungan yang membentuk masyarakat. Dalam kelompok dengan bahasa yang beragam, seorang penutur akan memasukkan tujuan dia bertutur, apa yang akan dibicarakannya, dan mengapa dia menggunakannya. Dari maksud penutur menggunakan bahasa, timbullah variasi, fungsi, dan jenis bahasa yang senantiasa berubah karena perbedaan lawan bicara.

Orang yang memiliki kemampuan berkomunikasi dengan menggunakan lebih dari satu bahasa disebut bilingual atau multilingual (Mackey dan Fishman, dalam Nababan, 1991). Menurut kajian Winreich yang dikutip Chaer dan Agustina (1995), menguasai dua bahasa dapat berarti menguasai dua sistem kode, dua dialek, atau ragam bahasa yang sama. Bahasa dan kode mempunyai hubungan timbal balik, artinya bahasa adalah kode dan sebuah kode dapat saja berupa bahasa. Peristiwa campur kode atau bahkan alih kode yang biasa terjadi dalam percakapan lisan juga dapat terjadi dalam percakapan atau dialog (bahasa lisan yang dituliskan). Ada dua gejala kebahasaan berkaitan dengan perubahan kode kebahasaan ini, yaitu alih kode dan campur kode. 
Appel (1976: 79) mendefinisikan alih kode sebagai gejala peralihan pemakaian bahasa karena berubahnya situasi Berbeda dengan gagasan tersebut, Hymes (1974: 103) berargumentasi bahwa alih kode tidak hanya terjadi antarbahasa, tetapi dapat juga terjadi di antara ragam dan gaya yang terdapat dalam satu bahasa. Nababan yang dikutip Suandi (2014: 139) mengungkapkan bahwa campur kode adalah percampuran antara dua bahasa atau lebih dalam suatu tindak bahasa (speech act atau discourse) tanpa ada sesuatu dalam situasi berbahasa itu yang menuntut pencampuran bahasa. Namun, melibatkan masalah kesantaian dan kebiasaan yang diikuti oleh penutur. Campur kode terjadi apabila seorang penutur menggunakan suatu bahasa secara dominan. Kemudian tuturannya disisipi dengan unsur bahasa lain. Hal ini biasanya berhubungan dengan karakteristik penutur, seperti latar belakang kelas sosial, tingkat pendidikan, dan rasa keagamaan. Suwito (1983: 78-80) menjelaskan bahwa campur kode dapat dibedakan menjadi beberapa macam penyisipan unsur berwujud: (1) kata, (2) frasa, (3) baster, (4) perulangan kata, (5) ungkapan atau idiom, dan (6) klausa.

Pembahasan tentang gejala campur kode melibatkan konteks dan ko-teks. Leech (1983) menjelaskan konteks sebagai salah satu komponen dalam situasi tutur yang berkaitan dengan lingkungan fisik dan sosial sebuah tuturan. Leech menambahkan bahwa konteks adalah pengetahuan yang menjadi latar belakang, yang secara bersamaan dimiliki oleh penutur dan mitra tutur sehingga konteks dapat membantu mitra tutur menafsirkan atau menginterprestasi maksud tuturan penutur. Menurut Hymes, suatu konteks harus memenuhi delapan komponen yang biasa diakronimkan sebagai S-P-E-
A-K-I-N-G (Chaer dan Agustina, 1995: 62). Adapun yang dimaksud dengan koteks adalah teks yang berhubungan dengan sebuah teks yang lain. Ko-teks dapat berupa unsur teks dalam sebuah teks yang wujudnya kalimat, paragraf, dan bahkan wacana yang berperan untuk mendukung atau memperjelas makna.

Perkembangan masyarakat bahasa dari monolingual kemudian menjadi bilingual, dan pada akhirnya menjadi multilingual disebabkan oleh banyak faktor. Perkembangan teknologi komunikasi dianggap turut mendorong globalisasi pengetahuan. Demikian juga pesatnya perkembangan dunia pendidikan meningkatkan kebutuhan masyarakat untuk menguasai berbagai bahasa dunia, terutama bahasa Inggris.

\section{METODE PENELITIAN}

Metode yang digunakan dalam penelitian ini adalah metode kualitatif dengan teknik pemaparan data deskriptif. Menurut Bogman dan Taylor seperti yang dikutip Moleong (1997: 3), metode penelitian kualitatif adalah prosedur penelitian yang menghasilkan data deskriptif berupa kata tertulis atau lisan dari perilaku orang-orang yang dapat diamati. Penelitian kualitatif lebih menghendaki arah bimbingan penyusunan teori substantif yang berdasarkan data. Metode deskriptif adalah metode penelitian yang berusaha menggambarkan dan menginterprestasi objek sesuai dengan apa adanya (Sukardi, 2003). Langkah-langkah dalam penelitian ini dimulai dari pembacaan novel dan penandaan pada bagian-bagian yang memuat gejala campur kode. Selanjutnya, data dikumpulkan dan diklasifikasikan berdasarkan kategori kebahasaan: (1) kata (nomina, verba, adjektiva, konjungsi, interjeksi), (2) frasa (frasa nominal, frasa preposisional, frasa adjektival), (3) baster, (4) klausa, dan (5) 
idiom. Seluruh data campur kode bahasa Inggris dari kelima klasifikasi di atas diterjemahkan dan dianalisis dengan pendekatan sosiolinguistik.

Kajian terhadap fenomena campur kode yang terdapat di dalam novel Antologi Rasa dilakukan dengan menganalisis berdasarkan faktor linguistik dan faktor ekstralinguistik. Dalam analisis linguistik, data diklasifikasikan berdasarkan wujud campur kode, yaitu dari penyisipan kata, frasa, baster, klausa, dan idiom. Data yang mengandung campur kode tersebut dipaparkan menurut deskripsi intensi dan acuannya. Dalam analisis ekstralinguistik, data dibahas dengan mengaitkan faktor eksternal atau unsurunsur di luar kaidah bahasa. Dalam menerjemahkan data, digunakan kamus ekabahasa Inggris-Inggris dalam jaringan https://dictionary.cambridge. org/dictionary/english.

\section{PEMBAHASAN}

Pembahasan terdiri atas dua bagian, yaitu analisis linguistik dan ekstralinguistik. Kedua analisis tersebut diuraikan dalam subbab berikut.

\section{Analisis Linguistik}

\section{Penyisipan kata}

Kata merupakan satuan bahasa yang dapat berdiri sendiri, berasal dari morfem tunggal atau gabungan morfem (Kridalaksana, 2008). Berdasarkan data yang terkumpul terdapat wujud campur kode berupa penyisipan kata yang kemudian dibagi menjadi beberapa kelas kata, yaitu nomina, verba, adjektiva, konjungsi, dan interjeksi.

\section{Nomina}

Nomina merupakan kategori yang secara sintaktik tidak mempunyai potensi untuk (1) bergabung dengan kata tidak dan (2) mempunyai potensi untuk didahului kata dari (Kridalaksana, 2008). Beberapa data yang ditemukan diuraikan sebagai berikut.

(1) "Hon, udah makan? ... Aku udah di hotel sama Keara ... (hal. 219)

(2) "Ehm, sekedar pernyataan disclaimer gue di depan ya, Panji ini punya reputasi player." (hal. 101)

(3) "Hai," aku menyambut Caleb yang berlari ke pelukanku begitu aku turun dari mobil di driveway rumah Dinda. (hal. 91)

Nomina Hon (1) adalah bentuk pangkas dari nomina afektif honey 'sayang'. Honey memiliki makna a name that you call someone you love or like very much 'sebuah panggilan untuk seseorang yang sangat dicintai atau disayangi'. Dalam bahasa lisan, sering dilakukan proses apokope, yaitu hilangnya satu bunyi atau lebih pada akhir kata sehingga honey dipangkas menjadi hon. Panggilan penuh cinta ini ditujukan Dinda, sahabat Keara, kepada suaminya. Meskipun, perempuan itu menganut prinsip kebebasan, tetapi ia sangat menjaga keutuhan keluarganya. Kata hon digunakan penutur karena berhubungan dengan kebiasaan dan pengaruh kehidupan yang pernah ia jalani di Amerika yang dimaksudkan untuk memanggil pasangan atau kekasih hati.

Nomina disclaimer (2) berarti a formal statement saying that you are not legally responsible for something, such as the information given in a book or on the internet, or that you have no direct involvement in it "pernyataan formal yang mengatakan bahwa Anda tidak bertanggung jawab secara hukum untuk sesuatu, seperti informasi yang terdapat di dalam buku atau internet, atau bahwa Anda tidak terlibat langsung di 
dalamnya'. Ujaran ini dituturkan oleh Dinda kepada Keara. Keara yang sedang patah hati berusaha dijodohkan dengan Panji yang memiliki sifat sering memainkan perasaan perempuan. Pemilihan kata disclaimer digunakan Dinda untuk memperingatkan Keara dan sebagai penekanan pemertahanan diri Dinda apabila di suatu hari hal-hal yang tidak diinginkan terjadi.

Sifat Panji dijelaskan pada klausa berikutnya "[...], Panji ini punya reputasi player." Nomina player berasal dari verba to play 'memainkan' Nomina ini mengalami pergeseran makna, dari makna someone who takes part in a game or sport or acting 'seseorang yang berperan serta dalam permainan atau olahraga atau akting' menjadi player yang bermakna memperlakukan atau memperdayakan perempuan sesuka hati. Biasanya player tidak berorientasi memiliki hubungan percintaan jangka panjang. Penggunaan campur kode pada ujaran ini lebih mengena langsung pada maksudnya. Alih-alih menggunakan leksem bahasa Indonesia, penulis lebih leluasa memakai leksem bahasa Inggris sebagai bentuk penekanan konotasi negatif sehingga memberi makna yang lebih mendalam.

Nomina Driveway (3) berarti a short private road that leads from a street to a person's house or garage (building where a car is kept) 'jalan pribadi pendek yang mengarah dari jalan ke rumah atau garasi seseorang (bangunan tempat mobil disimpan)'. Kata ini disebutkan oleh Keara saat dirinya berkunjung ke rumah Dinda. Dalam bahasa Indonesia tidak ditemukan padanan kata untuk menyebutkan jalan seperti itu, terlebih konstruksi budaya awal rumah di Indonesia tidak mengenal adanya driveway. Oleh karena itu, penulis memilih menggunakan kata driveway untuk mendeskripsikan lokasi kendaraan berhenti.

\section{Adjektiva}

Adjektiva adalah kategori yang ditandai oleh kemungkinannya untuk (1) bergabung dengan kata tidak, (2) mendampingi nomina, (3) didampingi kata-kata seperti: lebih, sangat, agak, (4) mempunyai ciri morfologis seperti $-e r$ (dalam honorer), -if (dalam sensitif), - $i$ (dalam alami), atau (5) dibentuk menjadi nomina dengan konfiks ke-an, seperti adil menjadi keadilan, halus menjadi kehalusan, yakin menjadi keyakinan (Kridalaksana, 2007). Berikut beberapa data adjektiva.

(4) "Gimana gue nggak excited, coba?" (hal. 15)

(5) Oh great. Ternyata selain menjurus bangkrut secara finansial, aku juga terancam tertular virus H1V1 gara-gara perjalanan ini. (hal. 16)

(6) ... menit demi menit berlomba membuktikan siapa yang lebih passionate dalam hubungan ini (hal. 202)

Adjektiva excited (4) berarti feeling very happy and enthusiastic 'perasaan sangat bahagia dan bersemangat'. Adjektiva atributif ini menerangkan suasana hati "gue" atau penutur, yaitu Harris. Leksem ini menggambarkan perasaan hati yang berkaitan dengan kekuatan dan gairah semangat. Sesuai konteks cerita, Harris senang dan sangat bersemangat karena akan menyaksikan balap mobil kelas dunia Formula 1 di Singapura. Kata excited dirasa lebih kuat dan mengena pada situasi ujaran tersebut. Selain itu, penutur menekankan nilai prestise pengguna bahasa campur kode.

Adjektiva Oh great (5) diujarkan Keara saat mengeluh karena dia harus mengisi form bebas flu burung ketika tiba di bandara Singapura. Interjeksi tersebut termasuk ragam bahasa lisan anak muda atau slang yang memiliki 
makna kontradiktif dengan makna sebenarnya. Seruan itu menggambarkan suatu hal yang terjadi di luar ekspektasi dan bersifat ironis. Adjektiva ini memiliki makna informal used to mean that something is very bad 'digunakan untuk menyebut sesuatu yang sangat buruk'. Penggunaan campur kode pada tuturan ini merupakan ekspresi spontan untuk menyatakan keterkejutan Keara. Karena Keara fasih berbahasa Inggris sehingga terlontar pilihan kata tersebut.

Adjektiva passionate (6) bermakna having very strong feelings or emotions 'memiliki perasaan atau emosi yang sangat kuat'. Dari konteks cerita, dijelaskan saat itu Keara sedang bepikir tentang hubungannya dengan Panji. Adjektiva passionate sebagai wujud campur kode menekankan bahwa di antara dua orang yang berhubungan asmara itu, siapa yang memiliki hasrat atau keinginan yang sangat kuat. Penggunaan kata passionate mengimplikasikan penekanan makna rasa.

Ketiga adjektiva tersebut di atas digunakan penutur sebagai bentuk pengungkapan tingkat sosial kelas menengah dan bernilai positif/apresiatif. Kemampuan berbahasa Inggris secara lancar seperti ini juga menunjukkan prestise penggunanya. Penggunaan bahasa Inggris dalam adjektiva tersebut juga mengindikasikan keakraban antarpenutur.

\section{Konjungsi}

Konjungsi adalah kategori yang berfungsi untuk meluaskan satuan lain dalam kontruksi hipotaktis, dan selalu menghubungkan dua satuan lain atau lebih dalam kontruksi (Kridalaksana, 2008). Berikut data mengandung konjungsi.

(7) Keara, though, si Keara ini beda. (hal. 141)
Adjektiva though memiliki makna despite the fact that 'terlepas dari kenyataan itu'. Ujaran ini merupakan pujian Ruly pada Keara yang tersimpan dalam hatinya. Pengunaan kata though mengimplikasikan bahwa di luar sifat Keara yang hedon dan suka mabuk, ia adalah perempuan yang kuat dan tidak sering mengeluh saat diberi tugas tambahan di kantor. Ruly sangat menyadari hal itu, terlebih nama Keara disebut dua kali di awal kalimat dan di tengah kalimat dengan penekanan partikel berupa kata sandang "si". Dalam hal itu, though menempati aposisi renggang, kata yang dibatasi oleh tanda koma (,). Konjungsi intra-kalimat though ini juga menekankan perlawanan makna atau tepatnya perihal yang berbeda dari sifat Keara. Penggunaan campur kode pada data ini lebih pada kebiasaan dan kemampuan tokoh berbicara dalam bahasa Inggris.

\section{Interjeksi}

Interjeksi adalah adalah kategori yang bertugas mengungkapkan perasaan pembicara dan secara sintaktik tidak berhubungan dengan kata-kata lain dalam ujaran, bersifat ekstrakalimat, dan selalu mendahului ujaran sebagai teriakan yang lepas atau berdiri sendiri (Kridalaksana, 2008). Berikut data yang memuat interjeksi.

(8) Shit, iPod gue ada di mana ya? Yang bener aja, mampus aja gue kalau hilang beneran. (hal.123)

Interjeksi shit (8) is used to express anger or surprise 'kata shit digunakan untuk mengekspresikan rasa marah atau keterkejutan'. Interjeksi sendiri merupakan kata yang biasa digunakan untuk mengungkapkan perasaan secara spontan, yang biasanya muncul pada awak kalimat. Berdasarkan konteks situasi, shit diterjemahkan 'sial'. Tuturan di atas diungkapkan Harris yang merasa 
kesal karena tidak dapat menemukan iPod-nya, benda yang selalu ia bawa ke mana pun, dan selalu mengingatkannya pada Keara. Perempuan kecintaannya itu pernah menyatakan bahwa apabila kita ingin mengenal karakter asli seseorang, cukup dilihat isi iPodnya. Campur kode shit ini merupakan bentuk ragam bahasa lisan anak muda yang biasa digunakan dalam kelompok sosial dengan relasi pertemanan.

\section{Penyisipan Frasa}

Frasa adalah gabungan dua kata atau lebih yang sifatnya tidak predikatif (Kridalaksana, 2008). Dari data yang dikumpulkan, ditemukan campur kode dengan wujud penyisipan frasa nominal, frasa preposisional, dan frasa adjektival.

\section{Frasa Nominal}

Frasa nominal adalah frasa yang induknya berupa nomina atau kata benda (Alwi, 2003, hal. 244).

Berikut beberapa data yang ditemukan.

(9) The charming laugh yang selalu mampu membuatku ikut tertawa. (hal. 37)

(10) Setiap aku merasa mengantuk, bosan, nggak tahan, muak, atau malah ingin menggampar my date of the night, aku biasanya permisi ke toilet [...] (hal. 67)

(11) Ada sedetik, dua detik awkward silence di antara aku dan dia setelah itu, sampai aku berkata, "Sayang, besok kita ketemu, ya?" (hal. 192)

(12) Cuma orang tolol yang mau naik premium cab dari bandara ke Kuningan di Sabtu malam Jakarta yang macetnya bikin bunuh diri ini. (hal. 239)

Frasa the charming laugh 'tawa yang menawan' (9) yang dimaksud adalah Harris. Harris memang menarik dan tampan, tetapi Keara tidak mencintainya. Walaupun begitu, Keara tetap terpana oleh tawanya. Dalam frasa tersebut terkandung gaya bahasa sinekdok pars pro toto, yaitu menyebutkan sebagian untuk keseluruhannya. Frasa ini terbentuk atas determinator the, adjektiva charming dan nomina laugh sebagai induknya. Laugh memiliki makna the act or sound of laughing 'tindakan atau bunyi tawa'. Charming berarti pleasant and attractive 'menyenangkan dan menarik'. Campur kode frasa the charming laugh ini mengindikasikan julukan atau nama yang diberikan sehubungan dengan keistimewaan seseorang. Keistimewaan Harris dengan tawanya yang khas memberi kesan pada Keara hingga ia memberikan sebutan khusus untuknya.

Frasa my date of the night (10) 'teman kencanku malam itu' merujuk pada laki-laki yang menjadi pasangan Keara saat makan malam. Keara tidak menyebut nama karena banyak laki-laki telah hadir dalam hidupnya dan tidak ada laki-laki yang benar-benar berkesan baginya, kecuali Ruly. Apabila mulai merasa bosan dan tidak tertarik, Keara biasanya melakukan sandiwara kecil dengan Harris untuk menyingkirkan laki-laki teman kencannya yang anonim itu. Frasa nominal my date of the night (adjektiva posesif + nomina + preposisi + determinator + nomina) memiliki induk nomina date dengan pembatas adjektiva posesif $m y$ yang menyatakan kepemilikan saya.

Nomina date bermakna a social meeting planned before it happens, especially one between two people who have or might have a romantic relationship 'pertemuan sosial yang direncanakan sebelumnya, khususnya pertemuan di antara dua orang yang memiliki atau mungkin memiliki hubungan romantis'. 
$\begin{array}{rrr}\text { Pembatas berikutnya } & \text { adalah } \\ \text { preposisi of dan nomina } & \text { night } \\ \text { 'malam'dengan determinator the }\end{array}$

Penggunaan campur kode my date of the night seolah menegaskan obyek yang menjadi pokok pembicaraannya selain tentu saja untuk meningkatkan gengsi dengan memakai bahasa Inggris.

Frasa nomina awkward silence 'keheningan yang ganjil' (11) yang terdiri dari adjektiva + nomina mendeskripsikan keheningan yang terjadi saat Keara hendak berpisah dengan Panji, kekasih pelariannya dari Ruly. Panji memanggil Keara babe 'sayang' yang mengingatkannya pada Harris. Yang berbeda, Keara selalu memarahi Harris bila memanggilnya seperti itu. Nomina silence yang menjadi induk memiliki makna a period without any sound; complete quiet 'saat tanpa suara sedikitpun, benar-benar tenang'. Adjektiva awkward yang berfungsi sebagai penjelas nomina berarti causing problems, worry, or embarrassment 'menyebabkan masalah, kekhawatiran atau perasaan malu'. Penggunaan campur kode pada frasa ini lebih pada fungsinya sebagai bahasa pergaulan atau slang. Kata awkward belakangan ini menjadi kosakata yang tren di kalangan anak muda.

Nomina premium cab (12) 'taksi bertarif mahal' terpaksa digunakan Harris untuk pulang dengan resiko harus membayar mahal ongkosnya. Ia merasa dirinya sebagai orang tolol yang sudah tahu akan rugi, tetapi tetap naik taksi itu juga. Ia tidak memiliki pilihan lain. Nomina $c a b$ sebagai inti frasa nominal adalah sebutan untuk taksi di Amerika. Adjektiva premium yang menbatasi nomina $c a b$ berarti refer to something that is of higher than usual quality 'merujuk pada sesuatu berkualitas lebih tinggi dari yang biasanya'. Campur kode pada frasa ini dimaksudkan untuk menekankan angkutan mewah yang bertarif cukup mahal karena taksi dengan kelas premium sudah pasti kendaraan yang terbaru dan modern.

Selanjutnya, pada data 13 terdapat nomina sebagai berikut.

(13) Hei, gue nggak ada rasa apa-apa dengan si Kinar ini, dia cuma bagian dari orang-orang yang gue pilih untuk membantu gue dalam rutinitas 'murdering Keara from my mind' itu. (hal. 109)

Nomina murdering Keara from my mind 'menyingkirkan Keara dari pikiranku' adalah tindakan Harris yang berusaha 'membunuh' atau melupakan bayangan Keara dari ingatannya. Lakilaki ini pun berhubungan kembali dengan perempuan-perempuan yang tergila-gila padanya, misalnya Kinar. Frasa ini berinduk pada nomina murdering yang merupakan gerund, yaitu nomina verbal yang dibentuk dengan sufiks -ing dan menjadikannya uncountable noun 'nomina yang tak bisa dihitung'. Frasa tersebut berfungsi sebagai obyek. Murdering memiliki makna kias if you say that something is murder, you mean it is very difficult or takes a lot of work 'jika Anda mengatakan sesuatu membunuh 'murder', maksudnya, hal tersebut sangat sulit atau membutuhkan banyak usaha'.

Campur kode ini berperan menekankan aktivitas menghilangkan pikiran tentang Keara di kepala Harris. Penggunaannya lebih pada pengakuan akan kemampuan bahasa Inggrisnya dan juga estetika berbahasa. Pemilihan kata ini menimbulkan efek dan kesan dari maknanya.

\section{Frasa Preposisional}

Frasa preposisional atau frasa depan adalah frasa yang terdiri atas kata depan sebagai penanda, diikuti oleh kata atau frasa sebagai aksisnya (Ramlan, 
1987, hal. 178). Berikut data yang mengandung frasa preposional.

(14) On most nights, aku cuma perlu menahan-nahankan diri paling lama sejam, sebelum akhirnya Harris muncul [...] (hal. 67)

Frasa on most nights 'di kebanyakan malam' menjelaskan bahwa Keara kerap pergi ke luar pada malam hari untuk makan di restoran atau minum di wine bar. Preposisi on sebagai induk frasa bermakna used to show when something happens 'digunakan untuk menunjukkan waktu terjadinya sesuatu'. Determinator most membatasi nomina nights dan memiliki arti almost all 'hampir semua/setiap'. Kata nights 'malam' merujuk pada waktu Keara menunggu Harris. Campur kode pada data tersebut di atas berfungsi sebagai penegas dari intensitas waktu yang dilewati Keara. Selain karena letaknya di awal kalimat sebagai keterangan waktu, penggunaan bahasa Inggris juga menekankan peran frasa itu.

\section{Frasa Adjektival}

Frasa adjektival adalah frasa endosentris yang berinduk satu yang induknya adverbial dan modifikatornya adverbial lain atau partikel (Kridalaksana, 2008).

Berikut data mengandung frasa adjektival.

(15) Gue masih lost for words saat Keara memegang tangan keriput si nenek, mengajaknya mengobrol [...] (hal. 177)

Dari konteks cerita dipaparkan bahwa Ruly tertegun saat melihat Keara yang dia kira egois dan tak acuh, ternyata begitu ramah saat berbicara dengan orang tua. Frasa lost for words 'terpana' menerangkan keadaan "gue" atau Ruly. Adjektiva lost yang menjadi inti memiliki makna not confident and not knowing what to do in a particular situation 'tidak percaya diri dan tidak tahu apa yang harus dilakukan dalam situasi tertentu'. Ruly terpana melihat tingkah laku Keira terhadap nenek sehingga ia kehilangan kata-kata.

Rully yang juga penah mengecap kehidupan di luar negeri memiliki kebiasaan menggunakan bahasa Inggirs. Jadi, campur kode pada tuturan ini muncul karena kemampuan berbahasa Inggris tokoh.

\section{Penyisipan Baster}

Baster merupakan hasil perpaduan dua unsur bahasa yang berbeda dan membentuk satu makna (Suwito, 1985, hal. 76). Dalam data yang ditemukan, baster memadukan afiksasi bahasa Indonesia dengan unsur-unsur bahasa Inggris. baster.

Berikut data yang mengandung

(16) "Gila lo ya, masa sampe jumlah umbrella girls-nya aja elo hafal." (hal. 16)

(17)Kenapa kalau bersama gue, Keara selalu bersikap seenaknya, naikin kaki ke dasbor mobil, menoyor gue, ber-fuck-shit-crap dalam setiap kalimat yang diucapkan. Sementara di depan Ruly, dia selalu seperti calon Putri Indonesia dalam proses penjurian [...] (hal.125)

(18) Mungkin seharusnya ku-garage sale-kan saja semua benda-benda itu, ya. (hal. 189)

(19) [...] aku tidak pernah berhenti terpana setiap kali Dinda menunjukkan sisi wife slash mother-nya ini. (hal. 219)

Ujaran di atas ditujukan Keara pada Harris, saat menemani laki-laki itu menonton balap mobil F1 di Singapura. Harris sangat menyukai dunia balap sehingga ia mengetahui banyak fakta 
yang berkaitan dengan kegemarannya tersebut. Kata umbrella girls (16) 'gadis payung' adalah sebutan yang ditujukan pada sekelompok perempuan muda dan cantik. Biasanya, mereka menggunakan rok mini dan berada di sirkuit balap motor atau mobil. Untuk menahan teriknya sinar matahari, mereka menggunakan payung untuk melindungi para pembalap. Umbrella girl atau istilah lainnya grid girl biasanya menemani pebalap di samping mobil balap sambil memegang payung sebelum memulai balapan di sirkuit. Baster ini terbentuk atas nomina umbrella dan nomina girl yang diikuti partikel penegas -nya. Campur kode ini digunakan penutur karena belum ditemukan padanan yang sesuai untuk kosakata ini.

Tuturan (17) “[...] ber-fuck-shitcrap merupakan kebiasaan Keara yang ditandai Harris saat dirinya bersama Harris. Kata "ber-fuck-shit-crap" merupakan bentuk verba. Namun, kata tersebut merupakan kata hibrida, yaitu kata kompleks yang bagian-bagiannya berasal dari campuran bahasa. Kata tersebut terbentuk dari paduan prefiks ber- (bahasa Indonesia) dan kosakata asing berupa makian berbentuk nomina fuck-shit-crap (bahasa Inggris). Dalam kaidah bahasa Indonesia awalan bermemiliki fungsi sebagai pembentuk verba dan memiliki makna menggunakan atau memakai.

Sementara itu, fuck-shit-crap merupakan bentuk tindakan ofensif. Kata-kata tersebut bermakna expressing extreme anger, or to add force to what is being said, nonsense, or something of low quality, insults, criticism, or unkind or unfair treatment 'mengekspresikan kemarahan, menekankan pada apa yang dikatakan, omong kosong, sesuatu yang berkualitas rendah, penghinaan, kritik, atau perlakuan tidak adil.' Campur kode dalam ujaran ini digunakan untuk menjelaskan kata-kata makian dalam bahasa Inggris yang sering digunakan oleh Keara. Ujaran yang menggunakan campur kode ini dimaksudkan untuk memberi penekanan akan kebiasaan Keara. Keara sering menggunakan kata fuck, shit, dan crap sebagai seruan ekspresi kemarahan, keterkejutan, atau sekedar bersenda gurau. Selain karena faktor kedekatan antarteman, hal itu juga dipengaruhi oleh kebiasaan dan kemampuannya dalam berbahasa Inggris yang sangat lancar.

Keara berniat mengobral bendabenda yang dibelinya saat ke Singapura bersama Harris tahun lalu. Benda-benda itu menyesakkan pikirannya dan melekat pada kenangan buruk tentang laki-laki itu dan terutama tentang Ruly. Kata garage sale (18) terbentuk dari nomina garage dan nomina sale yang berarti an outdoor sale of used personal or household items held on the seller's premises 'penjualan barang-barang pribadi atau rumah tangga bekas di tempat penjual'.

Campur kode kata garage sale digunakan karena tidak ada padanannya dalam bahasa Indonesia. Kegiatan berniaga ini merupakan budaya masyarakat Amerika, yang menjual barang bekas layak pakai dari kediaman mereka. Dalam ujaran baster ini menjadi frasa hybrid, artinya menggunakan imbuhan dalam kaidah bahasa Indonesia, yaitu pengimbuhan $k u$ - yang bermakna pelaku tindakan dan sufiks -kan yang memberi makna verba. Dengan demikian, makna dari kata ku-garage sale-kan sama dengan 'aku jual'. Keara bermaksud menjauhkan benda-benda yang mengingatkannya pada Harris dan peristiwa di Singapura.

Frasa wife slash mother istri atau ibu' (19) merupakan penilaian positif dari Keara untuk Dinda. Sahabatnya itu sangat nakal dan juga menjadi player di saat muda. Namun, ketika berhadapan dengan suami dan anak-anaknya, Dinda 
berubah drastis, ia menjadi sangat keibuan dan penyayang. Frasa nominal ini memiliki inti wife walaupun terdapat nomina lain mother. Posisi wife yang berada di awal frasa menguatkan kedudukannya sebagai yang utama. Wife berarti the woman to whom a man is married; a married woman 'perempuan yang dinikahi seorang lelaki; perempuan yang telah menikah', sementara mother memiliki makna a female parent 'orang tua perempuan'. Nomina yang berada di antaranya, slash berarti oblique (stroke) used to mean "or", or to show that something has two uses 'garis miring yang berarti "atau", atau untuk menunjukkan bahwa sesuatu memiliki dua kegunaan'.

Sesuai konteksnya, Keara sangat menghargai dan menekankan tindakan Dinda yang berperan baik sebagai istri sekaligus ibu, terutama melalui pemarkah partikel penegas -nya yang mengikuti frasa berbahasa Inggris. Fungsi campur kode pada sitasi dalam data menegaskan peran Dinda. Dengan menggunakan bahasa Inggris Keara menunjukkan pula rasa kagumnya.

\section{Penyisipan Klausa}

Klausa ialah satuan gramatikal berupa kelompok kata yang sekurangkurangnya terdiri dari subyek dan predikat, dan mempunyai potensi untuk menjadi kalimat (Kridalaksana, 2008). klausa.

Berikut contoh penyisipan

(20) "Eh, gue nggak ngerti beneran deh sama elo. Up until Singapore ya, all I hear is Ruly this and Ruly that, sampai bosan sendiri gue [...]." (hal. 100)

(21)So the hell with all these message from the office, yang kuperlukan sekarang cuma mandi untuk mencuci semua setan yang menguasai kepalaku. (hal. 278)
Klausa (20) Up until Singapore ya, all I hear is Ruly this and Ruly that 'Sampai Singapura ya, yang ku dengar hanya Ruly begini, Ruly begitu' adalah sindiran Dinda pada Keara yang bingung dengan perasaannya sendiri pada Ruly. Terkadang Keara tampak begitu bahagia dan jatuh cinta. Namun, pada saat lain, yang sering terjadi adalah Keara terpuruk karena cintanya pada Ruly tidak berbalas. Laki-laki itu hanya memandangnya sebagai teman yang mengasyikkan. Penggunaan klausa berbahasa Inggris dan dicampur dengan klausa bahasa Inggris menunjukkan kemampuan bilingual penutur.

Klausa (21) So the hell with all these messages from the office '[aku] tidak peduli dengan semua pesan dari kantor' adalah isi hati Keara yang baru saja menerima banyak pesan di ponselnya. Beberapa di antaranya dikirim oleh Harris dan Panji. Akan tetapi, tidak ada satu pun pesan dari Ruly. Nomina hell berarti used to express anger or to add emphasis 'digunakan untuk mengungkapkan rasa marah atau untuk menambah penekanan'.

Campur kode dengan wujud klausa tersebut menekankan bahwa pesan yang diterima Keara dari kantor tidaklah penting. Gadis itu lebih ingin melakukan hal yang lain, yaitu membersihkan tubuhnya dan beristirahat. Dalam hal ini, Keara menggunakan bahasa Inggris untuk menunjukkan perasaannya karena terbiasa mengungkapkan emosi dalam bahasa itu.

\section{Penyisipan Idiom}

Idiom adalah konstruksi dari unsur-unsur yang saling memilih, anggota masing-masing mempunyai makna yang ada hanya karena bersama yang lain (Kridalaksana, 2008).

Berikut beberapa data yang mengandung penyisipan idiom. 
(22) Gue mencintai lo seperti itu, Key. The more you make me suffer, the more I find I love you. (hal. 59)

(23) You know what, Rul, mungkin aku harus benar-benar menaklukkan kamu di Bali ini [...] (hal. 170)

Pada data (22) terdapat klausa [...] the more you make me suffer, the more I find I love you '[...] semakin kamu membuatku menderita, semakin aku tahu aku mencintaimu' adalah ungkapan hati Harris saat memandangi Keara. Ia tahu dan menderita karena perempuan itu hanya menganggapnya sebagai teman. Ia tahu tidak ada harapan untuknya karena Keara mencintai Ruly. Harris merasa sedih sekaligus bertekad untuk terus mencintai Keara.

Ungkapan the more..., the more... bermakna used for saying that when a particular activity, feeling etc increases, it causes something else to change at the same time 'digunakan untuk mengatakan bahwa ketika aktivitas tertentu, perasaan dll. meningkat, itu menyebabkan sesuatu yang lain berubah pada saat yang sama'. Campur kode ini memberi fungsi penekanan pada kata suffer 'menderita' dan I love you 'aku mencintaimu' dan memberi kesan dramatis.

Dalam data (23) terdapat klausa you know what ... Klausa ini diungkapkan oleh Keara saat merasa tertantang mendengar Ruly menyatakan dirinya tidak ingin menjadi salah satu korban Keara yang dikenal di kantor sebagai player. Keara selama ini merasa justru dialah yang sebenarnya menjadi korban dari sikap dan perhatian Ruly. Ungkapan you know what merupakan idiom yang bermakna used to emphasize the statement that comes after it 'digunakan untuk menekankan pernyataan yang datang setelahnya'. Klausa berikutnya mengungkapkan keinginan Keara untuk menundukkan
Ruly. Jelas bahwa peran campur kode tersebut sesuai fungsi dari idiom you know what, yaitu sebagai penegas.

\section{Analisis Ekstralinguistik}

Latar belakang Ika Natassa yang melewati masa kecilnya di Amerika (seperti Keara) dan profesinya sebagai sebagai bankir berpengalaman di Jakarta (juga seperti Keara) membuatnya fasih berbicara dan menulis dengan banyak ungkapan berbahasa Inggris. Hal ini langsung terlihat dari ucapan terima kasihnya di bagian awal Antologi Rasa yang seluruhnya menggunakan bahasa Inggris (Natassa, 2018, hal. 7-11). Selain itu, seperti telah dijelaskan dalam pendahuluan, hampir seluruh karya Ika menggunakan judul berbahasa Inggris di antaranya A Very Yuppy Wedding, The Architecture of Love, Critical Eleven, dan Dwivortiaire. Ika Natassa juga memberikan sentuhan personal pada judul setiap bab novel Antologi Rasa yang menggunakan idiom dan kalimat berbahasa Latin, misalnya Utrum per hebdomadem perveniam yang dijelaskan artinya di bagian bawah teks (dalam bahasa Inggris) If I can just get through this week (hal. 13), atau Fac ut gaudeam yang berarti Make my day (hal. 91).

Temuan tersebut telah menunjukkan bahwa penggunaan campur kode di dalam novel Antologi Rasa menjadi rasional karena berkaitan dengan faktor linguistik dan ekstralinguistik. Tokoh utama, Keara, memiliki banyak paralelitas dengan penulis novel, Ika Natassa. Penulis pernah bersekolah di Amerika, bekerja di bank asing, dan menjalani pergaulan metropolitan. Penulis tersebut dalam kesehariannya juga kerap menggunakan bahasa Inggris secara lisan maupun tulisan. Kebiasaan berbahasa penulis ini terjadi karena ada kontak budaya dan bahasa yang mewujud dalam fenomena 
campur kode. Temuan ini juga menunjukkan bahwa faktor ekstralinguistik sangat berpengaruh dalam kemampuan berbahasa para tokoh.

\section{PENUTUP}

Dari analisis linguistik, diketahui bahwa wujud campur kode yang terdapat dalam novel Antologi Rasa berupa (1) penyisipan kata yang kemudian dibagi atas kelas kata, yaitu nomina, verba, adjektiva, konjungsi, dan interjeksi, (2) penyisipan frasa berupa frasa nominal, frasa preposisional, dan frasa adjektival, (3) penyisipan baster, (4) penyisipan klausa, dan (5) penyisipan idiom.

Dari faktor linguistik dapat disimpulkan bahwa penggunaan campur kode dalam novel ini karena kefasihan para tokoh dalam berbahasa Inggris. Penutur juga menggunakannya untuk memperjelas maksud dengan memilih penekanan makna kata berbahasa Inggris. Tidak jarang, campur kode tersebut terjadi karena tidak ditemukannya padanan kosakata tertentu dalam bahasa Indonesia.

Faktor ekstralinguistik yang memengaruhi terjadinya campur kode dalam novel Antologi Rasa terutama adalah latar belakang penulis novel tersebut, Ika Natassa, yang sejak kecil tinggal di Amerika, dan karirnya sebagai bankir di sebuah bank asing di Jakarta. Ia juga telah terbiasa menggunakan Bahasa Inggris secara lisan dan tulisan.

Secara keseluruhan, dapat disimpulkan bahwa para tokoh dan narator di dalam novel Antologi Rasa, yaitu Keara, Harris, dan Ruly, ditampilkan sebagai sosok-sosok muda metropolitan yang secara aktif dan konsisten menggunakan bahasa Indonesia dan bahasa Inggris untuk berkomunikasi. Para tokoh, terutama Keara dan Harris, tampak sangat leluasa melakukan campur kode, baik saat berbicara dengan tokoh-tokoh lain, maupun ketika melakukan monolog dalam hati mereka. Penggunaan campur kode dapat dianggap menunjang kategorisasi dan labelisasi novel Antologi Rasa sebagai sebuah karya metropop. Kajian ini dapat membuktikan gagasan bahwa karya metropop selalu menggunakan latar ruang kota sebagai tempat hidup para tokohnya. Selain itu, mereka juga digambarkan hidup dalam situasi finansial dan pendidikan yang mapan -tidak jarang pula merupakan lulusan universitas luar negeri, sehingga sering menggunakan campuran bahasa Inggris dan bahasa Indonesia dalam keseharian mereka.

\section{DAFTAR PUSTAKA}

Alwi, H. (2003). Tata bahasa baku bahasa Indonesia. Jakarta: Balai Pustaka.

Andelwis, K. C. . dkk. (2014). Analisis wacana novel "Antologi Rasa" dan gaya hidup hedonisme. Jurnal Komunikasi Massa, 1, 120.

Appel, Rena, G. H. \& G. M. (1976). Sosiolinguistiek. Het Spectrum.

Chaer, A., \& Agustina, L. (1995). Sosiolinguistik suatu pengantar. Jakarta: Rineka Cipta.

Harum, D. M. (2018). Konsep maskulin dalam karya metropop Antologi Rasa karya Ika Natassa. Sawerigading, 2(24), 165-175.

Hymes, D. (1975). Foundation in sociolinguistics. University of Pennsylvania Press.

Komariyati, N. (2017). Analisis aspek sosial budaya dalam novel Antologi Rasa karya Ika Natassa. NOSI, 5(5), 1-12. 
Kridalaksana, H. (2007). Kelas kata dalam bahasa Indonesia. Jakarta: PT Gramedia.

Kridalaksana, H. (2008). Kamus linguistik. Jakarta: Gramedia Pustaka Utama.

Leech, G. N. (1983). The Principles of pragmatics. Longman Group UK, Limited.

Moleong, L. J. (1989). Metodologi Penelitian Kualitatif. Bandung: Remaja Rosdakarya.

Nababan, P. W. J. (1991). Sosiolinguistik: Suatu pengantar. Jakarta: Balai Pustaka.

Natassa, I. (2018). Antologi Rasa. Jakarta: Gramedia Pustaka Utama.

Rahmasari, N. L. dkk. (2017). Campur kode bahasa Perancis dalam novel The Chocolate Heart karya Laura Florand. Jurnal Ilmu Budaya, 1(5), 1-11.

Ramlan. (1987). Sintaksis. Yogyakarta: CV. Karyono.

Rochmani, Siti, D. (2013). Analisis alih kode dan campur kode pada novel Negeri 5 Menara karya Ahmad Fuadi. Basastra Jurnal Penelitian Bahasa, Sastra Indonesia dan Pengajarannya, 1(2), 1-16.
Suandi, I. N. (2014). Sosiolinguistik. Yogyakarta: Graha Ilmu.

Sukardi. (2003). Metodologi penelitian pendidikan. Jakarta: Bumi Aksara.

Sumarsono, \& Partana, P. (n.d.). Sosiolinguistik. Yogyakarta: Sabda dan Pustaka Pelajar.

Suwito. (1983). Pengantar awal sosiolinguistik teori dan problema. Surakarta: UNS Press.

Suwito. (1985). Sosiolinguistik pengantar awal. Surakarta: Universitas Sebelas Maret.

Wahyuti, dkk. (2013). Campur kode pada novel $5 \mathrm{Cm}$ karya Donny Dhirgantoro dan implikasinya. Jurnal Kata: Bahasa, Sastra, dan Pengajarannya, 1(8), 1-12.

Cambridge Dictionary (English Dictionary)

https://dictionary.cambridge.org/ dictionary/english/ 